\title{
Nitrogen topdressing and application ways of fluazifop-p-butyl + fomesafen in weed control and agronomic performance of common bean
}

\author{
MATHEUS G. SILVA ${ }^{1}$, ORIVALDO ARF ${ }^{2}$ and PAULO E. TEODORO ${ }^{1}$ \\ ${ }^{1}$ Departamento de Fitotecnia, Universidade Estadual de Mato Grosso do Sul, UEMS, \\ Rodovia Aquidauana/UEMS, 16, 79200-010 Aquidauana, MS, Brasil \\ ${ }^{2}$ Departamento de Fitotecnia Faculdade de Engenharia de Ilha Solteira, FEIS, Universidade Estadual \\ Paulista Júlio de Mesquita Filho, UNESP, 56, 15385-000 Ilha Solteira, SP, Brasil
}

Manuscript received on July 2, 2014; accepted for publication on April 23, 2015

\begin{abstract}
The objective of this study was to investigate the effect of interaction between nitrogen topdressing and different application ways (active ingredients) a.i. fluazifop-p-butyl + fomesafen in weed control and agronomic performance of common bean. The experiment was conducted during winter 2003 in Selvíria/ MS. The experimental design used was a randomized block design with four replications in a factorial scheme $2 \times 7$. The first factor was composed by the absence or presence of nitrogen topdressing, while the second factor consisted of different application ways of fluazifop-p-butyl + fomesafen. The following variables were measured: leaf $\mathrm{N}$ content, dry matter of plants, yield components (number of pods plant $^{-1}$, number of grains plant ${ }^{-1}$, the average number of grains pod $^{-1}$ and mass of 100 grains), grain yield, phytotoxicity and weed control percentage. The nitrogen topdressing with $75 \mathrm{~kg} \mathrm{ha}^{-1}$ provided higher dry matter of plants, higher weed control and higher common bean yield of irrigated winter. In the absence of nitrogen topdressing in the application of urea before or together to fluazifop-p-butyl + fomesafen increased their effectiveness in controlling weeds without interference in the agronomic performance of common bean.
\end{abstract}

Key words: nitrogen fertilization, herbicide mixture, Phaseolus vulgaris L., urea.

\section{INTRODUCTION}

Brazil is the largest producer of common beans (Phaseolus vulgaris L.), with a production estimated at 2.8 million tonnes in 2012 (Fao 2013) and average productivity of $939 \mathrm{~kg} \mathrm{ha}^{-1}$, obtained this crop (Conab 2014). However, this productivity is low considering the productive potential of the beans, which can reach $4,500 \mathrm{~kg} \mathrm{ha}^{-1}$. There are several problems that contribute to this fact, as the

Correspondence to: Paulo Eduardo Teodoro

E-mail: eduteodoro@hotmail.com improper management of nutrients, pests, diseases and weeds.

In Brazil, the fertilization with nitrogen $(\mathrm{N})$ in coverage is a practice that has provided yield increases of bean (Arf et al. 2011, Farinelli et al. 2006, Meira et al. 2005, Arf et al. 2014). The topdressing with $\mathrm{N}$ is also associated with an effective weed management because as verified by Sweeney et al. (2008) and Khan et al. (2012) this practice provided better weed control due to the higher growth rate of corn. Currently, the addition of nitrogen sources as adjuvant to herbicide is 
being investigated. This practice has been linked to reduction of doses and better absorption and translocation of molecules, as evidenced by Carvalho et al. (2008) and Ruas et al. (2012), who concluded that the addition of urea to glyphosate increased the control of several weed species, decreasing its required dose.

Among the main active ingredients used for chemical weed control in common bean are the fluazifop-p-butyl and fomesafen. The fluazifop-pbutyl is enzyme inhibitor acetil-CoA carboxylase, used to control of grasses. The fomesafen belongs to the group of protoporphyrinogen oxidase inhibitors (PPO or PROTOX), used for control of annual broadleaved species (Silva et al. 2007).

Araújo et al. (2008) verified that the application of these active ingredients (a.i.) together with molybdenum did not reduce the weed species control in common bean. However, no scientific study evaluated the effectiveness of applying fluazifop-p-butyl + fomesafen in association with urea in weed control.

Thus, the objective of this study was to evaluate the effect of interaction between nitrogen topdressing and different application ways of a.i. fluazifop-p-butyl + fomesafen in weeds control and agronomic performance of common bean.

\section{MATERIALS AND METHODS}

The experiment was conducted during the winter 2003 in the city of Selvíria/MS (51 $22^{\prime} \mathrm{W}$ and $20^{\circ} 22^{\prime} \mathrm{S}$ ), with altitude of $335 \mathrm{~m}$. The soil type is Oxisol Red Distrophic Typical clayey according to according to the criteria of Embrapa (2013). The average annual rainfall is $1,370 \mathrm{~mm}$, the annual average temperature is $23.5^{\circ} \mathrm{C}$. The chemical analysis for the layer $0-0.20 \mathrm{~m}$, performed before the establishment of the experiment, showed the following results: $\mathrm{pH}\left(\mathrm{CaCl}_{2}\right)=4.7$; Organic matter $=23 \mathrm{~g} \mathrm{dm}^{-3} ; \mathrm{K}, \mathrm{Ca}, \mathrm{Mg}$ and $\mathrm{H}+\mathrm{Al}=2.1,8.0,14.0$ and $34.0 \mathrm{mmol}_{\mathrm{c}} \mathrm{dm}^{-3}$, respectively; $\mathrm{V}=41 \%$.

The experimental design was a randomized block with four replications, in factorial $2 \times 7$.
The first factor was composed by the absence or presence of nitrogen topdressing, while the second factor consisted of different application ways of a.i. fluazifop-p-butyl + fomesafen: $150+120 \mathrm{~g}$ ha $^{-1}$ of a.i.; $150+120 \mathrm{~g} \mathrm{ha}^{-1}$ of a.i. together urea $(6 \%)$; urea (6\%) and subsequent application of 150 $+120 \mathrm{~g} \mathrm{ha}^{-1}$ of a.i.; $225+180 \mathrm{~g} \mathrm{ha}^{-1}$ of a.i.; $225+$ $180 \mathrm{~g} \mathrm{ha}^{-1}$ of a.i. together urea (6\%); urea $(6 \%)$ and subsequent application of $225+180 \mathrm{~g} \mathrm{ha}^{-1}$ of a.i.; without weed control. The plots consisted of six rows of beans with $6.0 \mathrm{~m}$ long, spaced $0.45 \mathrm{~m}$, and distributed 13 seeds per meter.

The population of weeds in the experimental area was composed mostly by Oryza sativa, Bidens pilosa, Brachiaria decumbens, Cenchrus echinatus, Panicum maximum, Amaranthus deflexus, Commelina benghalensis, Euphorbia heterophylla and Ipomoea grandifolia. This vegetation was desiccated with glyphosate at 1,500 $\mathrm{g} \mathrm{ha}^{-1}$. The cultivar IAC Carioca Eté was mechanically sown on 16 April 2003, in tillage system, ten days after desiccation using a simple seeder.

The basic fertilization was $200 \mathrm{~kg} \mathrm{ha}^{-1}$ of formulation 08-28-16, applied in the furrows sowing. The $\mathrm{N}$ topdressing was $75 \mathrm{~kg} \mathrm{ha}^{-1}$, as urea $(45 \% \mathrm{~N})$, applied on surface at 28 days after plant emergence. Subsequently the area was irrigated for incorporation of urea and reducing losses by volatilization.

The supply of water was carried out by a conventional fixed sprinkler irrigation system with average precipitation of $3.3 \mathrm{~mm} \mathrm{~h}^{-1}$ in the sprinklers. The water management during the development of the crop was performed using the Kc recommended by Doorenbos and Kassam (1979), distributed between plant emergence and harvest.

The application of active ingredients (a.i.) was performed on 16 May 2003, under ideal conditions of temperature, humidity and wind. The applications were done with costal sprayer, equipped in rod with three flat spray tips XR Teejet $8002 \mathrm{~S}, 50 \mathrm{~cm}$ spaced, with a pressure of $1 \mathrm{bar}$, set to consumption of diluted spray $200 \mathrm{~L} \mathrm{ha}^{-1}$. All 
applications were done while the common bean plants were in the V4 stage.

The following variables were measured: leaf nitrogen content (LNC) according to the methodology proposed by Sarruge and Haag (1974), dry matter of plants (DMP) and yield components (number of pods per plant, number of grains per plant, average number of grains per and mass of 100 grains) in five plants of each plot. The grain yield was estimated collecting two central rows of each plot, correcting up to $13 \%$ of wet basis and extrapolating the values for hectare.

The phytotoxic effect was evaluated in five plants per plot with the aid of a visual scale according to the methodology recommended by the Ewrc (1964). To determination of the percentage of weed control incidents in the area was followed by the methodology proposed by Alam (1974).

The variables analyzed were initially submitted to the Shapiro-Wilk's test to verify the normality of the residuals and Bartlett's test to evaluation of variances homogeneity. Subsequently, the data were submitted to analysis of variance (ANOVA) and averages were compared by Tukey's test at 5\% probability. The statistical analyzes were conducted using the statistical software Genes (Cruz 2006).

\section{RESULTS AND DISCUSSION}

The nitrogen topdressing $(\mathrm{N})$ provided higher dry matter (DMP) of plants and lower phytotoxicity (PHYT) (Table I). Taiz and Zeiger (2004) emphasized that in $\mathrm{C} 3$ plants, such as common beans, much of the $\mathrm{N}$ leaves is allocated in proteins involved in the photosynthetic process, especially in the enzyme Rubisco. This allows the inference that the nitrogen fertilization provides increased photosynthetic capacity of the plants, increasing the DMP.

\section{TABLE I}

Analysis of variance and mean values of dry matter per plant (DMP), leaf nitrogen content (LNC), phytotoxicity (PHYT) and weed control (WC), as function of application ways (A) of a.i. fluazifop-pbutyl + fomesafen, in presence or absence of nitrogen topdressing $(\mathrm{N})$ in irrigated common bean in winter. Selvíria (MS), 2003.

\begin{tabular}{|c|c|c|c|c|}
\hline Treatments & DMP $\left(\right.$ g plant $\left.^{-1}\right)$ & $\mathrm{LNC}\left(\mathrm{g} \mathrm{kg}^{-1}\right)$ & PHYT & WC $(\%)$ \\
\hline \multicolumn{5}{|l|}{ Topdressing fertilization $(\mathrm{N})$} \\
\hline Absence & $5.6 \mathrm{~b}$ & 28.0 & $3.0 \mathrm{a}$ & 65 \\
\hline Presence & $9.5 \mathrm{a}$ & 27.7 & $2.6 \mathrm{~b}$ & 85 \\
\hline LSD & 1.1 & - & 0.2 & - \\
\hline \multicolumn{5}{|l|}{ Application ways (A) } \\
\hline $150+120 \mathrm{~g} \mathrm{ha}^{-1}$ of a.i. & 6.4 & 28.2 & $1.7 \mathrm{~b}$ & 69 \\
\hline $150+120 \mathrm{~g} \mathrm{ha}^{-1}$ of a.i. + urea $(6 \%)$ & 7.8 & 26.9 & $2.0 \mathrm{~b}$ & 83 \\
\hline urea $(6 \%)$ and $150+120 \mathrm{~g} \mathrm{ha}^{-1}$ of a.i. & 6.9 & 29.1 & $2.3 \mathrm{~b}$ & 83 \\
\hline $225+180 \mathrm{~g} \mathrm{ha}^{-1}$ of a.i. & 9.2 & 29.1 & $2.3 \mathrm{~b}$ & 85 \\
\hline $225+180 \mathrm{~g} \mathrm{ha}^{-1}$ of a.i. + urea $(6 \%)$ & 7.7 & 27.4 & $3.5 \mathrm{a}$ & 90 \\
\hline urea $(6 \%)$ and $225+180 \mathrm{~g} \mathrm{ha}^{-1}$ of a.i. & 7.1 & 27.0 & $3.6 \mathrm{a}$ & 90 \\
\hline without weed control & 7.9 & 27.3 & $1.0 \mathrm{c}$ & 25 \\
\hline LSD & - & - & 0.6 & - \\
\hline $\mathrm{F}(\mathrm{N})$ & $46.3 *$ & $0.1^{\mathrm{ns}}$ & $6.7 *$ & $107.1 *$ \\
\hline $\mathrm{F}(\mathrm{A})$ & $1.4^{\mathrm{ns}}$ & $0.3^{\text {ns }}$ & $39.8 *$ & $76.3^{*}$ \\
\hline $\mathrm{F}\left(\mathrm{N}^{*} \mathrm{~A}\right)$ & $0.5^{\text {ns }}$ & $0.7^{\text {ns }}$ & $1.8^{\mathrm{ns}}$ & $4.6^{*}$ \\
\hline CV (\%) & 28.1 & 16.9 & 23.0 & 9.8 \\
\hline
\end{tabular}

Averages followed by the same letter in columns do not differ by Tukey's test at $5 \%$ significance; ${ }^{*}$ and ${ }^{\mathrm{ns}}$ : significant at $5 \%$ probability and not significant, respectively, by F-test; LSD: least significant difference; CV: coefficient of variation. 
The leaf nitrogen content (LNC) was not influenced by factors $\mathrm{N}$ and $\mathrm{A}$, remaining below the minimum level of nitrogen for the crop, which is $30 \mathrm{~g} \mathrm{~kg}^{-1}$ (Ambrosano et al. 1996). Similar results were obtained by Arf et al. (2011) and Chidi et al. (2002), who observed that the nitrogen topdressing not provided increment in this variable in relation to the control, linking this result to the efficiency of the natural microbial population to fix atmospheric N.

The application of urea before or along with the higher dose of fluazifop-p-butyl + fomesafen provided higher phytotoxicity (PHYT) to bean plants. Ruas et al. (2012) verified that the addition of urea at higher doses of glyphosate provided greater reduction in gas exchange and net $\mathrm{CO}_{2}$ assimilation of $B$. decumbens. This indicates that the addition of urea to the highest dose of fluazifop-p-butyl + fomesafen caused reduction in photosynthetic activity of bean, contributing to higher phytotoxicity.

There was a significant interaction $(\mathrm{p}<0.05)$ among $\mathrm{N} x \mathrm{~A}$ (Table II) for variable weeds control (WC). With the exception of treatment without weed control, the presence of topdressing fertilization provided higher WC. This is probably the biggest
DMP be associated with a larger plant, establishing greater shading on some weeds, preventing or hindering its germination and development.

In absence of nitrogen topdressing, the application of urea before or together the a.i. fluazifop-p-butyl + fomesafen increased the effectiveness of the doses used in WC. This was probably due to urea is a substance that go through with relative ease the cuticle of leaves, breaking its ester, ether and di-ether linkages, which contributes to greater absorption of other elements present in the diluted spray, consequently increasing the input spaces (Durigan 1992).

The A factor did not influenced the number of grains per plant (NGP), number of pods per plant (NPP), mass of 100 grains (MHG) and grain yield (YIE) (Table III). Similar results were obtained by Timossi and Durigan (2002), who did not find significant effect of different doses of fluazifop-pbutyl + fomesafen in agronomic performance of bean crop.

The variables NGP, NPP, NGP and MHG did not influenced by A factor, similarly to the results obtained by Meira et al. (2005), that do not observed influence of nitrogen topdressing on

TABLE II

Unfolding of significant interaction between the application ways (A) of i.a. fluazifop-p-butyl + fomesafen and application of nitrogen topdressing (N), on evaluation of weed control (WC) in irrigated common bean in winter. Selvíria (MS), 2003.

\begin{tabular}{|c|c|c|c|c|}
\hline & \multirow{2}{*}{ Treatments } & \multicolumn{2}{|c|}{ Topdressing fertilization $(\mathrm{N})$} & \multirow{2}{*}{ LSD } \\
\hline & & Absence & Presence & \\
\hline \multirow{7}{*}{$\begin{array}{l}\text { Application ways } \\
\text { (A) }\end{array}$} & $150+120 \mathrm{~g} \mathrm{ha}^{-1}$ of a.i.* & $57 \mathrm{bB}$ & $95 \mathrm{aA}$ & \multirow{7}{*}{10.5} \\
\hline & $150+120 \mathrm{~g} \mathrm{ha}^{-1}$ of a.i. + urea $(6 \%)$ & $70 \mathrm{abB}$ & $95 \mathrm{aA}$ & \\
\hline & urea $(6 \%)$ e $150+120 \mathrm{~g} \mathrm{ha}^{-1}$ of a.i. & $70 \mathrm{abB}$ & $95 \mathrm{aA}$ & \\
\hline & $225+180 \mathrm{~g} \mathrm{ha}^{-1}$ of a.i. & $75 \mathrm{abB}$ & $95 \mathrm{aA}$ & \\
\hline & $225+180 \mathrm{~g} \mathrm{ha}^{-1}$ of a.i. + urea $(6 \%)$ & $83 \mathrm{aB}$ & $100 \mathrm{aA}$ & \\
\hline & urea $(6 \%)$ and $225+180 \mathrm{~g} \mathrm{ha}^{-1}$ of a.i. & $83 \mathrm{aB}$ & $100 \mathrm{aA}$ & \\
\hline & without weed control & $25 \mathrm{cA}$ & $25 \mathrm{bA}$ & \\
\hline
\end{tabular}

Same letters in uppercase in the columns and lowercase in the rows do not differ by Tukey's test at 5\% probability; LSD: least significant difference. 
TABLE III

Analysis of variance and mean values of number of grains per plant (NGP), number of pods per plant (NPP), number of grains per pod (NGPO) mass of 100 grains (MHG) and grain yield (YIE) of common bean as function of application ways (A) of a.i. fluazifop-p-butyl + fomesafen, in presence or absence of nitrogen topdressing (A) in irrigated common bean in winter. Selvíria (MS), 2003.

\begin{tabular}{|c|c|c|c|c|c|}
\hline Treatments & NGP & NPP & NGPO & $\mathrm{MHG}(\mathrm{g})$ & YIE $\left(\mathrm{kg} \mathrm{ha}^{-1}\right)$ \\
\hline \multicolumn{6}{|l|}{ Nitrogen topdressing $(\mathrm{N})$} \\
\hline Absence & 45.6 & 10.0 & 4.6 & 18.5 & $1,660 \mathrm{~b}$ \\
\hline Presence & 47.7 & 9.9 & 4.8 & 18.2 & $1,878 \mathrm{a}$ \\
\hline LSD & - & - & - & - & 200 \\
\hline \multicolumn{6}{|l|}{ Application ways (A) } \\
\hline $150+120 \mathrm{~g} \mathrm{ha}^{-1}$ of a.i. $*$ & 49.7 & 10.3 & 4.8 & 18.1 & 1,736 \\
\hline $150+120 \mathrm{~g} \mathrm{ha}^{-1}$ of a.i. + urea $(6 \%)$ & 48.5 & 10.0 & 4.8 & 18.6 & 1,874 \\
\hline urea $(6 \%)$ and $150+120 \mathrm{~g} \mathrm{ha}^{-1}$ of a.i. & 49.3 & 10.4 & 4.7 & 18.4 & 1,809 \\
\hline $225+180 \mathrm{~g} \mathrm{ha}^{-1}$ of a.i. & 43.3 & 9.2 & 4.7 & 18.2 & 1,726 \\
\hline $225+180 \mathrm{~g} \mathrm{ha}^{-1}$ of a.i. + urea $(6 \%)$ & 44.3 & 10.2 & 4.4 & 18.6 & 1,733 \\
\hline urea $(6 \%)$ and $225+180 \mathrm{~g} \mathrm{ha}^{-1}$ of a.i. & 46.8 & 10.2 & 4.7 & 18.5 & 1,694 \\
\hline without weed control & 44.9 & 9.2 & 4.9 & 18.3 & 1,811 \\
\hline LSD & & - & - & - & - \\
\hline $\mathrm{F}(\mathrm{N})$ & $0.7^{\mathrm{ns}}$ & $0.1^{\mathrm{ns}}$ & $2.3^{\mathrm{ns}}$ & $2.6^{\mathrm{ns}}$ & $18.1^{*}$ \\
\hline $\mathrm{F}(\mathrm{A})$ & $0.6^{\mathrm{ns}}$ & $0.6^{\mathrm{ns}}$ & $0.6^{\mathrm{ns}}$ & $1.4^{\mathrm{ns}}$ & $0.9^{\text {ns }}$ \\
\hline $\mathrm{F}(\mathrm{N} * \mathrm{~A})$ & $1.0^{\mathrm{ns}}$ & $0.6^{\mathrm{ns}}$ & $0.6^{\mathrm{ns}}$ & $1.3^{\mathrm{ns}}$ & $1.4^{\mathrm{ns}}$ \\
\hline CV $(\%)$ & 20.1 & 18.3 & 13.4 & 2.6 & 10.9 \\
\hline
\end{tabular}

Averages followed by the same letter in columns do not differ by Tukey's test at 5\% significance; ${ }^{*}$ and ${ }^{\text {ns }}$ : significant at $5 \%$ probability and not significant, respectively, by F-test; LSD: least significant difference; CV: coefficient of variation.

primary components of bean crop. However, Portes (1996) reported that bean plants well nourished produces more flowers, and consequently there is an increase in NPP. The number of grains per pod (NGPO) did not significantly affected, possibly because this characteristic to be varietal and less influenced by the environment (Andrade et al. 1998). Nevertheless, Arf et al. (2004) observed that this variable was influenced by $\mathrm{N}$ doses applied in topdressing, indicating that better nutrition of $\mathrm{N}$ can increase the number of fertilized ovules per pod. The lack of significance for the MHG can be inferred that this feature has lower percentage variation resulting from changes in the cultivation environment (Crusciol et al. 2001), being more related to genotypic characteristics of the cultivar.
The $\mathrm{N}$ topdressing provided greater YIE to common bean. These results corroborate those obtained by Arf et al. (2011), Farinelli et al. (2006) and Meira et al. (2005), who verified that the nitrogen topdressing increased the common bean yield. According to Chidi et al. (2002), the response of common bean to nitrogen topdressing depends of cultivars and changes in climate, which indicates that this practice should be done when the cultivar IAC Carioca Eté is grown under conditions similar to this experiment.

\section{RESUMO}

O objetivo deste estudo foi verificar o efeito da interação entre a adubação nitrogenada em cobertura e diferentes modos de aplicação dos ingredientes ativos (i.a.) 
fluazifop-p-butil + fomesafen no controle de plantas daninhas e desempenho agronômico do feijoeiro comum. O experimento foi conduzido durante o inverno de 2003 em Selvíria/MS. O delineamento experimental utilizado foi em blocos casualizados com quatro repetições, em esquema fatorial $2 \times 7$. O primeiro fator foi composto pela ausência ou presença de adubação nitrogenada em cobertura, enquanto o segundo constituiu-se de diferentes modos de aplicação do i.a. fluazifop-p-butil + fomesafen. Foram mensuradas as seguintes variáveis: teor foliar de $\mathrm{N}$, matéria seca das plantas, componentes de produção (número de vagens planta ${ }^{-1}$, número de grãos planta ${ }^{-1}$, número médio de grãos vagem ${ }^{-1}$ e massa de 100 grãos), produtividade de grãos, fitotoxicidade e porcentagem de controle de plantas daninhas. A adubação nitrogenada em cobertura com $75 \mathrm{~kg} \mathrm{ha}^{-1}$ proporcionou maior matéria seca de plantas, maior controle de plantas daninhas e maior produtividade do feijoeiro comum de inverno irrigado. Na ausência da adubação nitrogenada em cobertura, a aplicação de uréia antes ou em conjunto ao fluazifop-p-butil + fomesafen aumentou sua eficácia no controle de plantas daninhas, sem interferência no desempenho agronômico do feijoeiro.

Palavras-chave: adubação nitrogenada, mistura de herbicidas, Phaseolus vulgaris L., uréia.

\section{REFERENCES}

ALAM - ASOCIACIÓN LATINOAMERICANA DE MALEZAS. 1974. Recomendaciones sobre unificación de los sistemas de evaluación en ensayos de control de malezas. Asoc Latin Mal 1: 35-38.

Ambrosano EJ, Wutke EB, Bulisani EA And CAntarella H. 1996. Feijão. In: Raij B et al. (Eds), Recomendações de adubação e calagem para o Estado de São Paulo, Campinas: IAC, p. 194-195.

ANDRADE MJB, Diniz AR, CARVALHO JG AND LIMA SF. 1998. Resposta da cultura do feijoeiro à aplicação foliar de molibdênio e às adubações nitrogenadas de plantio e cobertura. Ciên Agrotec 22: 499-508.

ARAÚJO GAA, SILVA AA, THOMAS A AND ROCHA PRR. 2008. Misturas de herbicidas com adubo molíbdico na cultura do feijão. Plant Dan 26: 237-247.

ARF MV, BuZETti S, ARF O, KAPPES C, FERREIRA JP, GITTI DC AND YAMAMOTO CJT. 2011. Fontes e épocas de aplicação de nitrogênio em feijoeiro de inverno sob sistema plantio direto. Pesq Agropec Trop 41: 430-438.
ARF O, Rodrigues FAR, SÁ ME, BuZETti S AND NASCIMENTO V. 2004. Manejo do solo, água e nitrogênio no cultivo de feijão. Pesq Agropec Bras 39: 131-138.

Arf O, Silva MG, BuzetTi S, SÁ ME AND TeOdoro PE. 2014. Influence of crop residues and nitrogen levels on agronomic performance of irrigated common bean. G Adv Res J Agric Sci 3: 284-288.

CARVAlHo SJP, DiAs ACR, NiCOlai VDM AND CHRistofFoleti PJ. 2008. Glifosato aplicado com diferentes concentrações de uréia ou sulfato de amônio para dessecação de plantas daninhas. Pesq Agropec Bras 43: 1501-1508.

Chidi SN, SORATTO RP, Silva TRB, ARF O, SÁ ME AND BUZETTI S. 2002. Nitrogênio via foliar e em cobertura em feijoeiro irrigado. Acta Scie Agron 24: 1391-1395.

CONAB - COMPANHIA NACIONAL DE ABASTECIMENTO. 2014. Acompanhamento da safra brasileira. Grãos 2012/2013. Décimo levantamento/Agosto 2013. Available at: <http:// www.conab.gov.br>. Access in: Aug 19, 2014.

Crusciol CAC, Lima EV, Andreotti M, Lemos LB, NAKAGAWA J AND FURLANI JUNIOR E. 2001. Adubação nitrogenada de semeadura e de cobertura sobre a produtividade do feijoeiro. Cult Agron 10: 119-133.

CRUZ CD. 2006. Programa Genes: Biometria. Viçosa: Editora UFV, $382 \mathrm{p}$.

DOORENBOS J AND KASSAM AH. 1979. Yield response to water. Roma: FAO, 193 p. (Irrigation and Drainage Paper, technical statement 33).

DURIGAN JC. 1992. Efeito de adjuvantes na calda e no estádio de desenvolvimento das plantas, no controle do capimcolonião (Panicum maximum) com glyphosate. Plant Dan 10: 39-44.

EMBRAPA - EMPRESA BRASILEIRA DE PESQUISA AGROPECUÁRIA. 2013. Sistema Brasileiro de Classificação dos Solos, Rio de Janeiro: Embrapa/CNPS, 353 p.

EWRC - EUROPEAN WEED RESEARCH COUNCIL. 1964. Cittee of methods in weed research. Weed Res 4: 88.

FAO - FOOD AND AGRICULTURE ORGANIZATION OF THE United NATIONS. 2013. Production - Crops. Available at: $<$ http://faostat.fao.org > . Access in: Apr 28, 2014.

FARINELLI R, LEMOS LB, PENARIOL FG, EGÉA MM AND GAsparoto MG. 2006. Adubação nitrogenada de cobertura no feijoeiro, em plantio direto e convencional. Pesq Agropec Bras 41: 307-312.

KHAN NW, KHAN N AND KHAN IA. 2012. Integration of nitrogen fertilizer and herbicides for efficient weed management in maize crop. Sar J Agri 28: 457-463.

MeIrA FA, SÁ ME, BuZETTI S AND ARF O. 2005. Doses e épocas de aplicação de nitrogênio no feijoeiro irrigado cultivado em plantio direto. Pesq Agropec Bras 40: 383388.

PORTES TA. 1996. Ecofisiologia. In: Araújo RS et al. (Eds), Cultura do feijoeiro comum no Brasil. Piracicaba: Potafos, p. 101-131. 
RUAS RAA, LIMA JCL, APPELT MF AND DEZORDI LR. 2012. Controle de Brachiaria decumbens Stapf com adição de ureia à calda do glifosato. Pesq Agropec Trop 42: 455-461.

SARRUGE JR AND HAAG HP. 1974. Análises químicas em plantas, Piracicaba: ESALQ, 56 p.

SILVA CM, FREITAS SP AND ROSA RCC. 2007. Efeito residual da aplicação de fluazifop-p-butil + fomesafen em solos com plantas-teste. Cienc Rural 37: 1450-1452.
SWEENEY AE, RENNER KA, LABOSKI C AND DAVIS A. 2008. Effect of fertilizer nitrogen on weed emergence and growth. Weed Scie 56: 714-721.

TAIZ L AND ZEIGER E. 2004. Fisiologia Vegetal. Porto Alegre: Artmed, $722 \mathrm{p}$.

TIMOSSI PC AND DURIGAN JC. 2002. Doses reduzidas de fluazifop-p-butil + fomesafen no controle de plantas daninhas na cultura da soja. Plant Dan 20: 439-447. 
